\title{
(CO)VARIANCES BETWEEN CATTLE POSTPARTUM BODY WEIGHT AND DAIRY TRAITS IN A PASTORAL SYSTEM IN CHILE
}

\section{COVARIANZAS ENTRE CARACTERISTICAS PRODUCTIVAS Y PESO POSTPARTO EN VACAS LECHERAS EN UN SISTEMA PASTORAL EN CHILE}

\author{
Héctor Uribe $^{1^{*}}$, y Humberto González ${ }^{1}$ \\ ${ }^{1}$ Departamento de Producción Animal, Facultad de Ciencias Agronómicas, Universidad de Chile, \\ Avenida Santa Rosa 11315, La Pintana, Santiago, Chile.. \\ * Autor para correspondencia E-mail: hector.a.uribe@gmail.com
}

\begin{abstract}
In Chile, the genetic parameters of dairy cow body weight have not been estimated due to lack of data. The objective of this study was to determine variance components of milk yield traits and postpartum body weight. Data were obtained from a dairy research farm in southern Chile. A multitrait animal mixed repeatability model was used and genetic parameters were estimated using the VCE software. Heritability estimates for yields of milk, milk fat and protein, and postpartum body weight were $0.26 \pm 0.011,0.30 \pm 0.011,0.27 \pm 0.012$ and $0.43 \pm 0.047$, respectively. Genetic correlations for postpartum body weight and yields of milk, milk fat and protein were $0.34,0.40$ and 0.38 , respectively. Phenotypic correlations were also positive and generally $10 \%$ lower than genetic correlations. It is concluded that the correlations between postpartum body weight and milk yield traits are positive and not very high. The genetic selection to favour yield would increase cow's body weight.
\end{abstract}

Key words: genetic correlation; milk solids; body weight; pastoral; heritability

\section{RESUMEN}

En Chile, debido a que no hay datos de peso corporal postparto en vacas, no se han estimado parámetros genéticos. En este estudio se estimaron componentes de varianza para características de producción de leche y peso vivo postparto. Los datos provienen de un plantel experimental de la Región de Los Lagos en Chile. Se usó un modelo lineal mixto multivariado con medidas repetidas y los parámetros genéticos fueron estimados usando el programa computacional VCE. Las estimaciones de heredabilidad para $\mathrm{kg}$ de leche, grasa y proteína y peso postparto fueron $0.26 \pm 0.011,0.30 \pm 0.011$, $0.27 \pm 0.012$ and $0.43 \pm 0.047$, respectivamente. Las correlaciones genéticas entre peso postparto y $\mathrm{kg}$ de leche, grasa y proteína fueron $0,34,0,40$ and 0,38 , respectivamente. Las correlaciones fenotípicas fueron también positivas y aproximadamente un $10 \%$ más bajas que las correlaciones genéticas. Se concluye que las correlaciones entre peso postparto y características productivas son positivas pero no muy altas. Además, la selección genética hacia un incremento en volúmenes de producción aumentaría el peso postparto de las vacas.

Palabras clave: correlaciones genéticas; sólidos en leche; peso corporal; pastoreo; heredabilidad

Received: 04 July 2018. Accepted: 06 August 2018. 


\section{INTRODUCTION}

Dairy farming is one of the most important economic activities in the rural southern area of Chile, where $70 \%$ of the national industrialized milk is produced (Lerdón et al., 2010; ODEPA 2017). Even though environmental factors are almost the same for both Los Ríos and Los Lagos regions (southern Chile), dairy farming does not follow a unique pattern to produce milk. There are several dairy production systems that primarily vary according to feeding input and cow breed. Cow size also varies by breed. Chilean local dairy specialists have not reached an agreement regarding the most convenient production system in terms of costs, and the corresponding cow breed and/or size. Therefore, cows of different breeds and body sizes, which have different nutritional requirements, can be found along the regions (Rauw et al., 1998).

Artificial insemination is routinely conducted in most dairy farms of Los Ríos and Los Lagos regions. At present, 95\% of frozen semen used is imported, mostly of Holstein Friesian from the USA (Osvaldo Ferreira, Cattle frozen semen importation officer, Agricultural and Livestock Service, Chile. Personal Communication). As this breed provides greater milk yield output, many dairy farmers in southern Chile prefer Holstein bulls for artificial insemination. In this sense, they are willing to purchase large amounts of concentrate feed to supply the nutritional demands of Holstein Friesian cows without paying attention to increments in body size as compared to less productive breeds.

The price of concentrate feed has increased more rapidly than that of raw milk. Because of this, some producers are shifting from a large proportion of concentrate to seasonal grazing pasture feeding, where the goal is to obtain optimal milk yields and milk solids per unit of land (González-Verdugo et al., 2004). In the last scenario, cow body size within a breed becomes an issue. In fact, larger and higher yielding cows may not be the most efficient to convert grass into milk, and milk solids in a seasonal pastoral system (Macdonald et al., 2008). In the last decade, Chilean dairy processing industries have been paying on milk solids rather than milk volume. This means that the economic success of dairy farmers in Southern Chile has become more dependent on milk solid output per unit of land rather than milk yield per cow (Delgadillo et al., 2016). Miglior et al. (2005) indicated that the focus of breeding programs worldwide has shifted from a yield-centered to a multi-faceted approach, including traits such as reproduction, longevity and body size, among others, and whose main goal is to improve farmers' profitability.

García et al. (2001) conducted a study on genetic parameters in dairy cows in Chile and used part of the data set used in this study (from 1978 to 1997), and reported very high genetic and phenotypic correlations between milk yield and milk fat yield, with values of 0.93 and 0.91 , respectively; estimated heritability for milk yield and milk fat yield was 0.35 and 0.31 , respectively.

Berry et al. (2002) estimated (co)variance components, among other traits, for body weight and milk yield at different stages of lactation from 74 dairy herds throughout Ireland; heritability estimates for body weight varied from 0.39 to 0.50 . Heritability estimates for milk yield were $0.19,0.24,0.26$ and 0.19 for $60,120,180$ and 240 days in milk, respectively. Phenotypic correlation between body weight at 5 days in milk, and cumulative milk yield at 240 days in lactation was estimated at 0.17; however, the same correlation at the genetic level was estimated at 0.09 , being not statistically different from zero. The authors concluded that cows that lose more body weight and body condition score in early lactation, tend to gain more body weight and body condition score in late lactation. Berry et al. (2003a) reported that genetic correlations between body weight at different days in milk and total lactation milk yield were all close to zero, but they became positive (up to 0.39) after adjusting body weight for differences in body condition score. In Chile, cow mature body weight is not routinely recorded in commercial dairy farms. Therefore, the data needed to study the potential associations between body weight and production traits are not available.

The objective of this study was to estimate (co) variance components for postpartum body weight and yields of milk, milk fat and milk protein in multiparous Frisón Negro dairy cows, using data gathered during 40 years in an experimental dairy cattle farm of Los Lagos region in southern Chile.

\section{MATERIALS AND METHODS}

\section{Data}

The raw data were 6,575 lactation records collected from 1973 through 2015 at Oromo Dairy Research Farm of the Universidad de Chile. The research farm is located in Purranque County ( $40^{\circ}$ 53' Lat. South, 73음 06' Lat. West; 114 m.s.n.m.), Osorno Province, Los Lagos Region in southern of Chile.

Data were collected following management procedures already put in place at Oromo dairy research farm. All cows are weighed within 12 hours after calving, while monthly milk recording is conducted by an external company 
on a monthly basis, from calving to either end of May or until the cow is dry. In fact, this farm may be the only one in Chile that can provide production and postpartum body weight data. Milk production at the research farm is from seasonally grazed pasture with a minimal addition of concentrate feed. This is offered from July to September, and thus early calving cows receive a greater amount than late calving cows. On average, the concentrate feed used is 70 grams per litre of milk. Calving is seasonal and mostly occurs in late winter as a way to synchronize seasonal pasture growth according to the cows' nutritional needs. Herd genetic improvement has been achieved using artificial insemination from sires with superior estimated breeding values for milk solids content rather than milk volume. In addition, body size of the cows has been maintained without increment, with these selection criteria having steered purchasing frozen semen from countries such as New Zealand and Ireland.

The cow breed used in this study is locally known as Frisón Negro breed. It is a black and white cow that can be described as an old Holstein Friesian type. Milk yield is lower and cow size smaller when compared to modern Holstein Friesian. In some areas of southern of Chile, the Frisón Negro is regarded as a dual-purpose breed (dairy and beef).

Milk recording is done monthly, from calving to either end of May or the cow is dry, by an independent milk recording agency. Monthly records of milk, fat and protein yields were estimated by the milking recording company by multiplying the yield of the corresponding test day by the number of days until the next test day; raw lactation yields were the sum of the monthly yields.

The raw data set had 5,932 records and after data editing, 4,896 lactation records were kept. These had complete information for at least one of the four traits: milk, milk fat, milk protein yields, and postpartum body weight. Inconsistent data and outliers were deleted in each trait; outliers corresponded to data falling above or below three standard deviations from the raw mean. The 4,896 lactation records were obtained from 1,446 cows by searching in the pedigree files; it was possible to include another 308 animals, mainly sires. Records of 155 cows had missing information regarding sire and dam identification number, but they were used for the analysis because those cows were dam of other cows that had records with complete data. Postpartum body weight was conducted as routinely recorded at the research station for each cow within 12 hours after calving.

The data were analysed using a multivariate four traits animal model solved by best linear unbiased prediction (BLUP) (Henderson, 1984). The traits included in the analysis were milk, milk fat, milk protein yields, and postpartum body weight.

\section{Statistical model}

Yields variables (milk, fat and protein) were all identically modelled as a function of a contemporary group (defined as a set of cows calving in the same calving season and year), parity number, and additive genetic and permanent environmental effects. Two calving seasons were defined: from June to October and from November to May. Days in milk was also included for all yield traits as a covariate. Animal genetics and permanent environmental effects were randomly treated in the model. Postpartum body weight was modelled same as the yield traits, but days in milk covariate was not included in its model. The multivariate model in matrix notation was:

$$
\begin{aligned}
\left(\begin{array}{l}
y_{1} \\
y_{2} \\
y_{3} \\
y_{4}
\end{array}\right)= & \left(\begin{array}{cccc}
X_{1} & 0 & 0 & 0 \\
0 & X_{2} & 0 & 0 \\
0 & 0 & X_{3} & 0 \\
0 & 0 & 0 & X_{4}
\end{array}\right)\left(\begin{array}{l}
b_{1} \\
b_{2} \\
b_{3} \\
b_{4}
\end{array}\right)+\left(\begin{array}{cccc}
Z_{1} & 0 & 0 & 0 \\
0 & Z_{2} & 0 & 0 \\
0 & 0 & Z_{3} & 0 \\
0 & 0 & 0 & Z_{4}
\end{array}\right)\left(\begin{array}{l}
a_{1} \\
a_{2} \\
a_{3} \\
a_{4}
\end{array}\right)+ \\
& \left(\begin{array}{cccc}
P_{1} & 0 & 0 & 0 \\
0 & P_{2} & 0 & 0 \\
0 & 0 & P_{3} & 0 \\
0 & 0 & 0 & P_{4}
\end{array}\right)\left(\begin{array}{l}
p_{1} \\
p_{2} \\
p_{3} \\
p_{4}
\end{array}\right)+\left(\begin{array}{l}
e_{1} \\
e_{2} \\
e_{3} \\
e_{4}
\end{array}\right)
\end{aligned}
$$

where: $y_{i}=$ vector of observations for the $\mathrm{i}^{\text {th }}$ trait, $b_{i}=$ vector of fixed effects for the $\mathrm{i}^{\text {th }}$ trait, $a_{i}=$ vector of random additive genetic effects for the $\mathrm{i}^{\text {th }}$ trait, $p_{i}=$ vector of random permanent environmental effects for the $\mathrm{i}^{\text {th }}$ trait, $e_{i}=$ vector of random residual effects for the $\mathrm{i}^{\text {th }}$ trait, $X_{i}, Z_{i}$ and $P_{i}$ are incidence matrices relating records of the $\mathrm{i}^{\text {th }}$ trait to fixed, random additive and random permanent environmental effects, respectively.

The (co)variance structure of the multivariate model was:

$$
\operatorname{Var}\left(\begin{array}{c}
a_{i} \\
p_{i} \\
e_{i}
\end{array}\right)=\left(\begin{array}{ccc}
G & 0 & 0 \\
0 & P & 0 \\
0 & 0 & R
\end{array}\right)
$$

where: $P$ and $R$ are matrices that contain permanent environmental variances $\left(\sigma_{p_{i}}^{2}\right)$ and residual variance $\left(\sigma_{e_{i}}^{2}\right)$ for the $\mathrm{i}^{\text {th }}$ trait in their diagonals, respectively. The off-diagonal elements has the permanent environmental covariance $\left(\sigma_{p_{i, i^{\prime}}}\right)$ and residual covariance $\left(\sigma_{e_{i, i^{\prime}}}\right)$ between traits $i$ and $i_{,}^{\prime}$ : respectively. $G$ is a matrix in which the diagonal contains the additive genetic variance $\left(\sigma_{a_{i}}^{2}\right)$, of the $i^{\text {th }}$ trait multiplied by the additive genetic relationship matrix $(A)$ and the off-diagonal elements has the additive genetic covariance $\left(A \sigma_{a_{i i^{\prime}}}\right)$ between traits $i$ and $i^{\prime}$.

The variance components were estimated 
by restricted maximum likelihood (Groeneveld, 1994) using the VCE 4.2.8 software (Kovac and Groeneveld, 2003).

\section{RESULTS}

Overall raw means, standard deviations, minimum and maximum values, and number of observations of the four traits are presented in Table 1. The number of observations was not equal for all traits; protein yield was the numerically least represented trait in the data set, having only 2,556 out of 4,896 observations (Table 2). This is due to the fact that protein yield only began to be recorded in Chile since 1995. The average body weight obtained from the 3,632 records was $48172.26 \mathrm{~kg}$ (Table 1). Milk yield per cow/lactation ranged from 1,646 to $7,985 \mathrm{~kg}$, with an average of 4,432 $\pm 1,224 \mathrm{~kg}$. The coefficient of variation of milk yield was $27.62 \%$, showing a degree of heterogeneity in the values of this variable. Minimal output for milk fat and protein were 47 and $68 \mathrm{~kg}$ per cow/lactation, respectively, while the maximum yield for the same traits was
364 and $278 \mathrm{~kg}$, respectively. Average milk fat and protein yields per lactation were $183.4 \pm 61.1$ and $172.6 \pm 34.7 \mathrm{~kg}$, respectively. The coefficient of variation for fat and protein yields were 33.31 and $201.12 \%$, respectively. Postpartum body weight averaged $481.54 \pm 72.25 \mathrm{~kg}$, recording the most homogeneous outcome in this study as its coefficient of variation was $15.00 \%$ (Table 1 ).

First and second lactations accounted for almost half of the data-set observations (49\%), while the fifth lactation provided only $9 \%$ of them; sixth and above lactations accounted for $14 \%$ of the records in the data set. There were 72 year-season interactions and frequencies varied from 1 to 145 observations. Days in milk average was $278 \pm 31$, ranging from 176 to 375 days.

Multivariate mixed models are able to handle missing observations, which means that all observations must not necessarily have all traits recorded. Table 2 shows the count record pattern of the observations within the data set, $51.8 \%$ of the 4,896 records had all four traits recorded. Milk fat yield was the most recorded single trait in the data set, being present in $99.8 \%$ of the records,

Table 1. Number of observations (n), means, standard deviations and minimum and maximum values of lactation milk yield, milk fat and protein yield and postpartum body weight from an experimental dairy cattle herd of Los Lagos region in southern Chile.

\begin{tabular}{lccccc}
\hline & n & Mean & Standard deviation & Minimum & Maximum \\
\hline Milk yield* & 4,846 & 4,432 & 1,224 & 1,646 & 7,985 \\
Fat yield * & 4,886 & 183.4 & 61.10 & 47 & 364 \\
Protein yield * $^{*}$ & 2,556 & 172.6 & 34.73 & 68 & 278 \\
Body weight $^{*}$ & 3,632 & 481.5 & 72.26 & 260 & 695 \\
\hline
\end{tabular}

$*=\mathrm{kg}$.

Table 2. Count record pattern for lactation milk yield, milk fat and protein yields and postpartum body weight from an experimental dairy cattle herd of Los Lagos region in southern Chile.

\begin{tabular}{ccccc}
\hline Milk yield & Fat yield & Protein yield & Postpartum body weight & Count \\
\hline X & $X$ & - & - & 1,215 \\
- & $X$ & - & - & 42 \\
X & $X$ & - & $x$ & 1,079 \\
- & - & $X$ & $x$ & 2 \\
X & $X$ & $X$ & - & 2,538 \\
X & $X$ & - & $x$ & 7 \\
- & $X$ & $x$ & $x$ & 2 \\
X & - & $x$ & $x$ & 7 \\
- & $X$ & $x$ & $x$ & 3 \\
- & - & 2556 & 3632 & \\
\hline 4846 & 4,886 & & & 4,896 \\
\hline Total of records & & & \\
\hline
\end{tabular}


followed by milk yield with $98.9 \%$. Postpartum body weight was in $74.2 \%$ of the records in the data set (Table 2).

The equations to be solved in the mixed model were 13,411 , while 108 rounds were needed for convergence, which was previously set at $1.0 \mathrm{x}$ $10^{-7}$ in the software parameter file. Phenotypic variance was the sum of the genetic, permanent environmental and residual estimated variances. Table 3 shows genetic, permanent environmental, residual and phenotypic estimated variances, and heritability for the four traits included in the analysis.

Heritability estimates of milk, milk fat and protein yields and postpartum body weight were $0.26 \pm 0.018,0.30 \pm 0.016,0.27 \pm 0.017$ and $0.43 \pm$ 0.047 , respectively (Table 3).

Table 4 shows the estimates of genetic and phenotypic correlations among the four traits included in this work. Correlations were all positive; at the genetic level, they varied from 0.34 to 0.83 between milk yield and postpartum body weight and milk and protein yields, respectively. Phenotypic correlations followed the same trend as genetic correlations, varying from 0.27 to 0.89 between the same traits indicated above. Genetic and phenotypic correlations between milk and fat yields were 0.64 and 0.77 , respectively.

\section{DISCUSSION}

\section{Phenotypic parameters}

Out of the 4,896 lactation records used in this study, only 2,538 (51.83\%) had observations in all traits (Table 2). However, this did not affect data analysis because multiple-trait mixed model methodology can deal with missing records and also different models for each trait (Henderson, 1984). In this sense, days in milk as a covariate was not included in the model used to explain variability of postpartum body weight because it was in the models for the other three traits.

The milk yield mean was $(4,432 \pm 1,224$ (Table1), and it is much lower than that reported by Elzo et al. (2004) and Uribe et al. (2017). They reported values of 7,502 $\pm 1,829$ and 7,606 $\pm 1,670$, respectively, adjusted to a 305-days mature equivalent. The data used in both studies were collected from cows that had more Holstein Friesian blood as opposed to cows used in this study, which were mainly New Zealand Friesian breed. Lembeye et al. (2016a) reported that the average milk yield, for medium production level New Zealand cows, was 4,101940, which is closer to the yield average reported in this work. This may be explained by the fact that Holstein frozen semen from New Zealand has been used to breed at Oromo Dairy Research Farm for many years.

Table 3. Estimates of genetic $\left(\sigma_{a}^{2}\right)$, permanent environmental $\left(\sigma_{p e}^{2}\right), \operatorname{residual}\left(\sigma_{e}^{2}\right)$ and phenotypic $\left(\sigma_{P}^{2}\right)$ variances, and heritability $\left(\boldsymbol{h}^{2}\right)$ of milk yield, milk fat and protein yields and postpartum body weight from an experimental dairy cattle herd of Los Lagos region in southern Chile.

\begin{tabular}{|c|c|c|c|c|c|}
\hline Trait & $\sigma_{a}^{2}$ & $\sigma_{p e}^{2}$ & $\sigma_{e}^{2}$ & $\sigma_{P}^{2}$ & $h^{2} \pm s e$ \\
\hline Milk yield & 100,174 & 75,217 & 209,344 & 384,735 & $0.26 \pm 0.018$ \\
\hline Fat yield & 230.50 & 92.32 & 434.52 & 757.33 & $0.30 \pm 0.016$ \\
\hline Protein yield & 114.76 & 73.76 & 231.05 & 419.56 & $0.27 \pm 0.017$ \\
\hline Body weight & $1,188.66$ & 388.34 & $1,222.39$ & $2,799.38$ & $0.43 \pm 0.047$ \\
\hline
\end{tabular}

Table 4. Estimates of genetic (above the diagonal) and phenotypic (below the diagonal) correlations between milk yield, fat and protein yield and postpartum body weight from an experimental dairy cattle herd of Los Lagos region in southern Chile.

\begin{tabular}{lcccc}
\hline & Milk yield & Fat yield & Protein yield & Body weight \\
\hline Milk yield & --- & $0.64 \pm 0.089$ & $0.83 \pm 0.207$ & $0.34 \pm 0.014$ \\
Fat yield & $0.77 \pm 0.065$ & ---- & $0.66 \pm 0.108$ & $0.40 \pm 0.043$ \\
Protein yield & $0.89 \pm 0.117$ & $0.79 \pm 0.068$ & --- & $0.38 \pm 0.053$ \\
Body weight & $0.29 \pm 0.008$ & $0.30 \pm 0.020$ & $0.27 \pm 0.022$ & ---- \\
\hline
\end{tabular}


In addition, the farm also counts with a seasonal milk production system, which is similar to that used in New Zealand.

Uribe and Smulders (2004) reported an average milk yield of 5,044 $\mathrm{kg}$ from 16 dairy Overo Colorado herds in southern Chile. These herds do not follow a typical pastoral seasonal production system, but most of the cows are mainly fed on pastures. Overo Colorado cattle is a dual purpose (dairy and beef) breed introduced in Chile by German immigrants. Conformation traits of this breed are similar to Frisón Negro breed. Their production traits are also similar, which is partially confirmed by comparing the results of Uribe and Smulders (2004) with the results of this work.

The consulted literature provide no information regarding body weight for southern Chile's dairy cattle as this trait is not usually recorded in Chilean dairy commercial farms. Therefore, there is no local data available for research. Lembeye et al. (2014) reported that New Zealand Friesian and crossbred (Friesian $x$ Jersey) cows had average body weights of 5046 and 4834 $\mathrm{kg}$, respectively. These findings are similar to the average postpartum body weight of $481.54 \mathrm{~kg}$ reported here (Table 1). Vallimont et al. (2010) conducted a study on the genetic parameters of feed intake, production and body weight of Holstein cows in 11 tie-stall Pennsylvanian farms, and reported that the average body weight of the cows, across herd, was $678 \mathrm{~kg}$. However, this result does not agree with the average postpartum body weight identified here (Table 1). This difference can be explained by the larger size of Holstein compared to Frisón Negro breed. However, a genetic study conducted by Tveit et al. (1991) on 334 first lactation Norwegian cows reported a similar postpartum body weight of 463 $\mathrm{kg}$. The Norwegian cows were fed grass silage al libitum and up to $6 \mathrm{~kg}$ of concentrate, which is different from the feeding allowance described above for the cows used in this study. Therefore, this may account for the larger body weight exhibited by Frisón Negro cows. In addition, this study included multiparous lactation cows, whereas the Norwegian study included primiparous cows only. A study on New Zealand Friesian cattle under seasonal grazing reported a body weight average of $404 \mathrm{~kg}$; this lower weight can be explained as a consequence of the negative selection emphasis on body weight of the New Zealand genetic selection index (Alawneh, 2011).

\section{Heritability}

Heritability estimate for milk yield was 0.26 \pm 0.011 . This is very similar to that reported by García et al. (2001) $(0.24 \pm 0.001)$, who used a subset of the data included in this study. This estimate $(0.26 \pm 0.011)$ is higher than that reported in two studies on Chilean dairy cows conducted by Uribe et al. (2017) and Montaldo et al. (2015), who reported values of $0.16 \pm 0.004$ and $0.19 \pm$ 0.006 , respectively. Uribe and Smulders (2004) found that heritability estimate for milk yield in Chilean Overo Colorado cattle was 0.25 , which is similar to that found in this study (Table 3). Overo Colorado breed is morphological similar to Frisón Negro breed, except for the fact that the former is red and white, while the latter is black and white. Another study on Chilean cows conducted by Elzo et al. (2004) reported heritability estimates for milk yield ranging from 0.31 to 0.34 , which are higher than those obtained here.

Heritability estimates for milk fat and protein yield were $0.30 \pm 0.011$ and $0.27 \pm 0.012$, respectively. Slightly higher estimates for milk fat yield (ranging from 0.29 to 0.37 ) were reported by Elzo et al. (2004), while heritability estimates for milk protein yield in Chilean cows ranged from 0.17 and 0.24 . These values are lower than the estimated parameter for the same trait in this work. Lembeye et al. (2016a) reported average heritability estimates for milk fat and milk protein yields of 0.25 and 0.24 , respectively, in low, medium and high producing New Zealand Holstein cows, milked twice a day. Both values were lower than those observed in this study (Table 3).

Postpartum body weight heritability estimate in this study was $0.43 \pm 0.047$. Estimates of this genetic parameter for Chilean cows were not found in the literature. The heritability estimated here falls in the low range of previous estimates for mature body weight. Tveit et al. (1991) reported a heritability estimate of 0.65 for 3 to 9 days body weight in Norwegian cows, which is higher than the heritability estimated here for the same trait. In this sense, the values reported by Tveit et al. (1991) are similar to those of Vallimont et al. (2010) in a study on commercial tie-stall Holsteins $(0.60 \pm 0.08)$. A much higher heritability estimate for body weight $(0.74 \pm 0.19)$ was reported by Ramatsona et al. (2015) for 9,843 South African Holstein cattle. Furthermore, Toshniwal et al. (2008) used a random regression model to estimate genetic parameters and determined heritability of electronically recorded daily body weight in Holstein cows of $0.46 \pm 0.06$, which is similar to that obtained here. In addition, Berry et al. (2003b) also fitted a random regression animal model using 91,937 Irish Holstein body weight records, and their heritability estimates varied from 0.48 to 0.61 from day zero to day 294 of lactation, respectively.

The methodology used by all studies 
discussed above is very similar to that used in this work. The (co)variance components were estimated by restricted maximum likelihood methodology (Groeneveld, 1994), solving different (single or multivariate) animal models using BLUP (Henderson, 1984) according to their own data structure.

\section{Correlations}

Estimates of phenotypic correlations between yield traits were all high and positive (Table 4). This partially agrees with the results of Sneddon et al. (2015), who reported phenotypic correlations between milk yield, and fat and protein yield of 0.75 and 0.92 , respectively. Similar results for pure bred Holstein cows were reported by Elzo et al. (2004) as the correlations for both traits were estimated at 0.82 and 0.88 , respectively. Similar high and positive estimates for the same traits were also reported by Lembeye et al. (2016 b) and Berry et al. (2003a), reaching 0.68 and 0.91 for milk yield, and 0.62 and 0.88 for fat and protein yield, respectively. García et al. (2001), who analysed part of the data set used in this research, identified a much higher phenotypic correlation between milk and milk fat yields (0.91).

Postpartum body weight was phenotypically low and positively correlated to yield traits. The estimates ranged from $0.27 \pm 0.022$ to $0.30 \pm 0.020$ (Table 4). This finding is not in agreement with that of Berry et al. (2002), who reported that the phenotypic correlation between body weight at 5 days of lactation and cumulative milk yield at 240 days of lactation was 0.17 . The phenotypic correlation identified in this study between milk yield and body weight was $0.29 \pm 0.008$, which is lower than that reported by Tveit et al. (1991) in Norwegian cattle, with an estimate of 0.38 between both traits.

Genetic correlations between milk yield and milk solids yield are generally reported as positive and high (Elzo et al., 2004; Lembeye et al., 2016a, b; Sneddon et al., 2015), as occurred in this study (Table 4). García et al. (2001) reported that the genetic correlation between milk yield and milk fat yield was 0.93 . However, the lowest genetic correlation in this study was found between milk yield and milk fat yield (0.64), which is similar to that reported by Toshniwal et al. (2008) (0.65 \pm 0.15 ) for Pennsylvanian and Virginian Holstein cows. The genetic correlation between milk yield and milk protein yield was the highest reported in this study, with a value of $0.83 \pm 0.207$ (Table $4)$, being similar to that reported by Toshniwal et al. (2008) (0.85).

Postpartum body weight was low, but positively correlated to all three yield traits. The genetic correlation for milk yield was $0.34 \pm 0.014$
(Table 4), which is lower than that reported by Tveit et al. (1991) (0.45) for Norwegian cattle. Different results were reported by Toshniwal et al. (2008) as they found no correlation between electronically daily recorded body weight and milk and milk fat and protein yields $(-0.14 \pm 0.18$, $0.11 \pm 0.24$ and $-0.07 \pm 0.16$, respectively), and those by Berry et al. (2002), who reported that estimated genetic correlation between body weight on day 5 of lactation and cumulative milk yield at day 240 of lactation was non-existent $(0.09 \pm 0.15)$. The results of Berry et al. (2003a) also disagree with those presented here. They reported close to zero genetic correlations between average body weight and yields of milk, milk fat and protein $(-0.01,0.03$ and -0.03 , respectively). However, all genetics correlations between body weight and yield traits became positive after adjusting body weight for differences in body condition score, and ranged between 0.15 and 0.39 .

The results obtained indicate that postpartum body weight is genetically and phenotypically associated with yield traits. These associations are positive but low, hence it is expected that as the output of milk, milk fat and protein improves due to genetic selection, body weight will also increase slowly. Larger body size cows tend to have higher maintenance cost, while their productive efficiency, measured as output per $\mathrm{kg}$ of body weight, is lower than that of smaller cows (Ramatsona et al., 2015). Therefore, body weight is a trait of economic importance. In addition, when using grazing-based production systems, cows must be able to walk long distances twice a day, from pasture to the milking parlour, and thus heavier cows may not be well suited to accomplish this task. Furthermore, if we consider that southern Chile has high rainfall, mostly concentrated in winter and spring seasons, which causes soil to get soft, heavier cows are in a disadvantageous position compared to lighter cows. To avoid unfavourable body weight changes while increasing yield traits, a selection index can be implemented similar to indexes implemented in New Zealand, and for pasturebased dairy producers in the United States (Gay et al., 2014) where body weight has a negative economic weight.

Estimates of genetic and phenotypic correlations between body weight and milk traits could be affected by genetic selection pressure on body weight in accordance with the dairy production system. By using frozen semen from countries such as New Zealand and Ireland, the selection emphasis of the herd providing data for this study was placed on improving milk solids content rather than milk yield, also adult cow body weight has been maintained without 
increment. Different data from intensive dairy production herds, in which body size has not been restricted, may yield different genetic and phenotypic correlation estimates.

The data size of this research is rather small (less than 1.500 cows providing phenotypic information) as compared to previous studies, also its structure, stretched along 42 years, are limitations that need to be addressed when discussing accuracy of these parameter estimates for potential applicability on the genetic improvement of any current dairy cattle population.

\section{CONCLUSIONS}

Genetic and phenotypic associations estimated in this study between postpartum body weight and yield traits, suggest that dairy yield traits increase as postpartum body weight increases. The medium to high heritability estimate for postpartum body weight $(0.43 \pm$ 0.047 ) suggests that there is scope for significant response to selection if this trait is included in a selection index.

\section{LITERATURE CITED}

Alawneh, I. J. 2011. Monitoring live weight to optimize health and productivity in pasture fed dairy herds. Ph.D. Dissertation, Massey University, Palmerston, New Zealand.

Berry, D.P., F. Buckley, P. Dillon, R.D. Evans, M. Rath, and R.F. Veerkamp. 2002. Genetic parameters for level and change of body condition score and body weight in dairy cows. J. Dairy Sci. 85:2030-2039.

Berry, D.P., F. Buckley, P. Dillon, R.D. Evans, M. Rath, and R.F. Veerkamp. 2003a. Genetic relationships among body condition score, body weight, milk yield, and fertility in dairy cows. J. Dairy Sci. 86:2193-2204.

Berry, D.P., F. Buckley, P. Dillon, R.D. Evans, M. Rath, and R.F. Veerkamp. 2003b. Genetic parameters for body condition score, body weight, milk yield and fertility estimated using random regression models. J. Dairy Sci. 86:3704-3717.

Delgadillo, J., H. González-Verdugo, and H. Uribe. 2016. Genetic-economic comparison of New Zealand Holstein and Jersey-New Zealand Holstein cross under a pastoral scheme in southern Chile. Arch. Med. Vet. 48:261-267.

Elzo, M.A., A. Jara, and N. Barría. 2004. Genetic parameters and trends in the Chilean multibreed dairy cattle population. J. Dairy Sci. 87:1506-1518.
García, X., J.C. Magofke, H. González, and A. Gargiullo. 2001. Parámetros genéticos en bovinos de leche. II. Estimaciones realizadas en un sistema de pastoreo con parición de primavera (X Región, Chile). Av. Prod. Anim. 26:49-62.

Gay, K.D., N.J.O. Widmar, T.D. Nennich, A.P. Schinckel, J.B. Cole, and M.M. Schutz. 2014. Development of a lifetime merit-based selection index for US dairy grazing systems. J. Dairy Sci. 97:4568-4578.

González-Verdugo, H., J.C. Magofke, and C. Mella. 2004. Productivity, intake and biological efficiency in New Zealand Friesian and F1 (Jersey-New Zealand Friesian) cows calved during late winter in the Xth Region, Chile. Arch. Med. Vet. 37:37-47.

Groeneveld, E. 1994. A reparameterization to improve numerical optimization in multivariate REML (co)variance component estimation. Genet. Sel. Evol. 26:537-545.

Henderson, C.R. 1984. Applications of linear models in animal breeding. 423 p. Univ. Guelph, Guelph, Ontario, Canada.

Kovac, M., and E. Groeneveld. 2003. VCE 5. User's guide and reference, Manual. Version 5.1. Available at http://vce.tzv.fal.de/manual/ index.html.

Lembeye, F., N. López-Villalobos, J.L. Burke, and S.R. Davis. 2014. Milk production, live weight, body condition and somatic cell score during the first 150 days of lactation in Friesian, Jersey and crossbred cows milked once daily. Proc. New Zeal. Soc. An. Prod. 74:5-10.

Lembeye, F., N. López-Villalobos, J.L. Burke, and S.R. Davis. 2016a. Estimation of genetic parameters for milk yield traits at different herd production levels in cows milked once or twice daily in New Zealand. Proc. New Zeal. Soc. of An. Prod. 76:49-53.

Lembeye, F., N. López-Villalobos, J.L. Burke, and S.R. Davis. 2016b. Estimation of genetic parameters for milk traits in cows milked once- or twice-daily in New Zealand. Livest. Sci. 185:142-147.

Lerdón, J., C. Muñoz, and V. Moreira. 2010. Productive and economic characterization of medium and large dairy farmers of southern Chile. IDESIA 28:41-49.

Macdonald, K.A., J.W. Penno, J.A.S. Lancaster, and J.R. Roche. 2008. Effect of stocking rate on pasture production, milk production, and reproduction of dairy cows in pasture-based systems. J. Dairy Sci. 91:2151-2163.

Miglior, F., B.L. Muir, and B.J. Van Doormall. 2005. Selection indices in Holstein cattle of various countries. J. Dairy Sci. 88:1255-1263. 
Montaldo, H.H., H. Castillo-Juárez, C. Lizana, C. Trejo, E.G. Cienfuegos-Rivas, and A. Pelcastre-Cruz. 2015. Genotype-environmental interaction between Chile and North America and Between Chilean herd environmental categories for milk yield traits in Black and White cattle. An. Sci. Pap. Rep. 33:23-33.

ODEPA 2017. Boletín de la leche: producción, recepción, precios y comercio exterior. [Dairy bulletin: production, reception, prices and foreign trade] Disponible en http:// www.odepa.cl/wp-content/uploads/2017/10/ Informe-lacteo.pdf

Ramatsona, N. I., C. B. Banga, K. C. Lehloenya, and R. Gibson. 2015. Estimation of genetic parameters for live weight in South African Holstein cattle. Open J. Anim. Sci. 5:242-248.

Rauw, W. M., E. Kanis, E. N. NoordhuizenStassen, and F. J. Grommers. 1998. Undesirable side effects of selection for high production efficiency in farm animals: a review. Livest. Prod. Sci. 56:15-33.

Sneddon, N. W., N. Lopez-Villalobos, S.R. Davis, R.E. Hickson, and L. Shalloo. 2015. Genetic parameters for milk components including lactose from test day records in the New Zealand dairy herd. New Zeal. J. Agr. Res. 58:97-107.
Toshniwal, J.K., C.D. Dechow, B.G. Cassell, J.A.D.R.N. Appuhamy, and G.A. Varga. 2008. Heritability of electronically recorded daily body weight and correlation with yield, dry matter intake, and body condition score. J. Dairy Sci. 91:3201-3210.

Tveit, B., M. Svendsen, and K. Hove. 1991. Heritability of hypocalcemia at first parturition in Norwegian cattle: Genetic correlations with yield and weight. J. Dairy Sci. 74:3561-3567.

Uribe, H., and J.P. Smulders. 2004. Phenotypic, environmental and genetic parameters and trend estimation for milk production traits in Overo Colorado cattle. Arch. Med. Vet. 36:137-146.

Uribe, H., H. González, and C. Gatica. 2017. Genetic parameter estimation to milk yield and fat and protein yield deviated from 3\% of concentration in milk, in dairy herds of southern Chile. Austral J. Vet. Sci., 49:71-76.

Vallimont, J.E., C.D. Dechow, J.M. Daubert, M.W. Dekleva, J.W. Blum, C.M. Barlieb, et al. 2010. Genetic parameters of feed intake, production, body weight, body condition score, and selected type traits of Holstein cows in commercial tie-stall barns. J. Dairy Sci. 93:4892-4901. 